\title{
Reciprocity Problem between Greece and Turkey: The Case of Muslim-Turkish and Greek Minorities
}

\author{
By Ali Dayıoğlu* \\ İlksoy Aslım ${ }^{\dagger}$
}

This study aims to show the position of the Greek and MuslimTurkish minorities from 1923 to 2014, a period during which Turkey and Greece had ups and downs in their relations, and the effects on the relevant minorities respectively. Since 1923 Turkey and Greece have taken their minority issues within the principle of reciprocity. Accordingly, the attitudes of the two countries towards their relevant minorities have been shaped according to the level of relations between them. When Turkey and Greece's relations have been moderate; minorities have benefited but when their relations soured, they suffered. Although Turkey-Greece relations developed rapidly after 1999, the new positive atmosphere has not fully affected the positions of the minorities. For example, opening the Halki Seminary School and the election of the Muftis has continued to act as an obstacle between Turkey and Greece. In this study, the problems concerning the implementation of the principle of reciprocity and also the impossibility of using this principle within the context of human and minority rights will be discussed.

\section{Introduction}

Based on the statement in article 45 in Section Three of the Lausanne Peace Treaty, "The rights conferred by the provision of the present Section on the non-Moslem minorities of Turkey will be similarly conferred by Greece on the Moslem minority in her territory" in Turkey and Greece, the issue of minorities is generally assessed within the scope of the principle of reciprocity. The reflection of this principle in Turkey is that if the Muslim-Turkish minority in Greece ${ }^{1}$ is oppressed, the same oppression is exerted on the Greeks in Turkey. For example, Turkey has put the election of the muftis by the Muslim-

\footnotetext{
*Assistant Professor, Lecturer, IR Department, Near East University, Cyprus.

${ }^{\dagger}$ Lecturer, Vice Chairperson, IR Department, Near East University, Cyprus.

${ }^{1}$ The reason why "Muslim-Turkish minority" has been preferred instead of "Turkish minority" or "Muslim minority" is that the Muslim minority in Greece, especially in Western Thrace, does not comprise only Turks, but Turks, Muslim Romas and Pomaks, and that the common ground between these three ethnic units is that they are Muslim. Nevertheless, it is worth pointing out that for various reasons the Muslim Romas and Pomaks in Western Thrace assumed the Turkish supra-identity and defined themselves as Turks (For more on this issue see Oran, B. Türk-Yunan Illişkilerinde Batı Trakya Sorunu (The Western Thrace Minority Question in Turco-Greek Relations) 2. B., Ankara: Bilgi Yayınevi, 1991):139-142.
} 
Turkish minority of Greece in Western Thrace as a precondition for opening the Halki Seminary, which was closed in 1971. Turkey used to claim that the muftis were to be elected by the Muslims of their districts in accordance with the Treaty of Athens (1913). Clearly, Turkey's case of opening the Halki Seminary is based on one of the most important principles of international law; the reciprocity principle. ${ }^{1}$

It should be said that Greece's policy is no different. For example, from 1955 to 1998 , the Greek administration used article 19 of the Greek Nationality Code No. 3370 to emigrate the Muslim-Turkish minority from Greece as a reprisal to the decline of the population of the Greek minority in Turkey. Another example can be given from Rhodes. In 1972, as a reaction to the closure of the Halki Seminary, the Greek government closed down the Turkish school. ${ }^{2}$ As of August 2014, there are no Turkish schools on the islands of Rhodes and Kos, where the minority live in apart from Western Thrace.

It is well known that the principle of reciprocity which means "the right to equality and mutual respect between states and ... involves permitting application of the legal effects of specific relationships in law when these same effects are accepted equally by foreign countries", can only be exercised against another state or its citizens ("foreigners"). It cannot be exercised in favor of its own citizens. Therefore, it should not be forgotten that members of the Greek minority are citizens of the Republic of Turkey and members of the Muslim-Turkish minority are citizens of Greece. Additionally, article 45 of the Treaty of Lausanne is not a reciprocity article but a "parallel obligation" article. ${ }^{4}$ Greece and Turkey have undertaken to reciprocally grant each other's minorities certain rights; not to violate the rights of each other's minorities. Moreover, article 60, clause 5 of the Vienna Convention on the Law of Treaties definitely forbids any form of reprisal with regard to human rights. As it is a sub-subject of human rights, this regulation is also valid in the case of minority rights. That's why in cases such as Apostolidis and others vs. Turkey, Nacaryan and Deryan vs. Turkey, Fokas vs. Turkey, the European Court of Human Rights (ECtHR) rejected Turkey's reasons for reciprocity. ${ }^{5}$

\footnotetext{
${ }^{1}$ A. Dayığlu, "Yunanistan'la İlişkiler", in: Baskın Oran ed. Türk Dış Politikası, Kurtuluş Savaşından Bugüne Olgular, Belgeler, Yorumlar, C. III, 2. B., (İstanbul, İletişim Yayınları, 2013), 560-631.

${ }^{2}$ For detailed information on these issues see ibid., 594-595 and 603-604.

${ }^{3}$ S. Akgönül, "Reciprocity and its Application in International Law", in: Samim Akgönül, ed., Reciprocity: Greek and Turkish Minorities, Law, Religion and Politics, İstanbul: İstanbul Bilgi University Press, 2008, p. 1-14.For detailed information on the application of the principle of reciprocity in international law see ibid., 1-14.

${ }^{4}$ T. Tarhanlı, Turgut Tarhanlı'nın Bildirisi, in: Cemaat Vakıfları, Bugünkü Sorunları ve Çözüm Önerileri, (İstanbul: İstanbul Barosu Yayını, 2002), 34-45.

${ }^{5}$ For these cases see Dayığlu, A. (2013), 611.
} 


\section{Negative and Positive Implementations of the Principle of Reciprocity}

Contrary to the spirit of Lausanne Treaty that has made the parties responsible for having parallel obligations towards their relevant minorities, the consequences have not always been as expected. The international atmosphere and the bilateral relations between Turkey and Greece have had a great impact on their attitudes towards the minorities. It is a fact that from the beginning they could not develop friendly relations because of the identity formation of the peoples in Greece and Turkey which were based on contrariety. However, when they had common enemies like Italy in the 1930s, and the Soviet Union after the 1950s, they became allies due to security concerns. In this context, Turkey and Greece cannot be described as traditional enemies, as Poulton put it; " their relations depended on the international atmosphere." Accordingly, during the periods when the parties had "moderate" relations their respective minorities lived in a more harmonious time, but when relations were again strained, the minorities, once again, began to suffer. Nonetheless, to better understand the concept of reciprocity, it is best to look at the history of the respectful parties. Nevertheless, one of the best ways to understand the implementation of the concept of reciprocity is to refer to the history of the relevant parties.

\section{Different Implementations of the Principle of Reciprocity in the 1920s and 1930s}

In January 1923, the convention between Greece and Turkey, namely, the "Convention Concerning the Exchange of Greek and Turkish Populations" was signed by Eleftherios Venizelos and İsmet İnönü. According to the convention; "Greek inhabitants of Constantinople" and the "Moslem inhabitants of Western Thrace" would not be included in the exchange. With the implementation of the convention, sizeable Muslim and Orthodox Christian minorities remained in Greece and Turkey respectively. Although it was a usual phenomenon during the nation-building process to ignore the minorities, the population exchange between Turkey and Greece caused great trauma. ${ }^{2}$

According to Oran, "reciprocity had an inherent weakness: It returned ill for ill as well as good for good." In any case, the arrival of 1.2 million

\footnotetext{
${ }^{1}$ H. Poulton, Top Hat Grey Wolf and Crescent: Turkish Nationalism and the Turkish Republic (London: Hurst \& Company, 1997), 295.

${ }^{2}$ On this issue see R. Hirschon, Ege'yi Geçerken: 1923 Türk-Yunan Zorunlu Nüfus Mübadelesi, (İstanbul: İstanbul Bilgi Üniversitesi Yayınları, 2005).

M. Pekin, Yeniden Kurulan Yaşamlar: 1923 Türk-Yunan Zorunlu Nüfus Mübadelesi, (İstanbul: İstanbul Bilgi Üniversitesi Yayınları, 2005)

O. Yıldırım, Diplomasi ve Göç: Türk-Yunan Diplomasisinin Öteki Yüzü,,( İstanbul: İstanbul Bilgi Üniversitesi Yayınları, 2006).

${ }^{3}$ B. Oran, "Reciprocity in Turco-Greek relations: The Case of Minorities", in: Samim Akgönül, ed. Reciprocity: Greek and Turkish Minorities, Law, Religion and Politics, (İstanbul, İstanbul Bilgi University Press, 2008), 36.
} 
migrants from Anatolia and 400,000 Muslims in Turkey resulted in countless economic and social problems. Confronted by many difficulties, both Greece and Turkey did not treat their minorities well; the election of religious leaders became problematic; while Greece began to appoint the muftis, electing the patriarchs in Turkey required her consent. Also, in Turkey the new rulers began economic nationalism and the bureaucratic restrictions forced many Orthodox Christians to migrate to Greece in the 1920s. ${ }^{1}$ On the other hand, Greece failed to form a stable government until 1928. The leaders of Greece and Turkey, Eleftherios K. Venizelos and Mustafa Kemal, showed a willingness to solve their problems with neighboring countries, and Turkey and Greece also agreed to settle the political and economic questions caused by the exchange of populations. In order to confront revisionist Italy and Bulgaria, the leaders of the two countries visited the other respectively and signed several agreements related to security, cooperation and trade. ${ }^{2}$ The friendly relations in the $1930 \mathrm{~s}$ had a major impact on the improvement in the treatment of the minorities in both countries. During these years Turkey ceased to interfere in the election of patriarchs and had warmer relations with the Greek-speaking minority. Greek schools and associations had fewer restrictions on their operations and activities. Greece acted in the same way, and the Muslim schools of Western Thrace dropped the Arabic script and switched to the Latin alphabet. It became easier for these schools to obtain textbooks and teachers from Turkey. ${ }^{3}$ Evidently, both treated their respective minorities congruent to the ups and downs of their bilateral relations. ${ }^{4}$

\section{Heyday of the Minorities (1950-1955)}

Being a member of NATO and the enmity against the Soviet Union contributed to the development of better relations between Turkey and Greece. Yet, Greece was critical towards Turkey in that she failed to carry out her obligations during the Second World War. Moreover, the Wealth Tax imposed by the Turkish government on the non-Muslims and the Greek minority caused a big disaster for all minorities. ${ }^{5}$ Consequently, it can be said that Turkey's

\footnotetext{
${ }^{1}$ A. Alexandris, The Greek Minority of Istanbul and Greek-Turkish Relations (1918-1974), (Athens: Centre For Asia Minor Studies, 1992), 105-112.

${ }^{2}$ M. Frrat, "Relations with Greece", in: B. Oran, ed. Turkish Foreign Policy (1919-2006): Facts and Analyses with Documents, (Salt Lake City: the University of Utah Press,2006), 207-209.

${ }^{3}$ Atatürk and Venizelos relations are explained best in D. Demirözü, Atatürk-Venizelos Dönemi Türkiye Yunanistan İlişkileri,( İstanbul: İletişim, 2007).

M. Frrat, "Relations with Greece", in: B. Oran ed. Turkish Foreign Policy (1919-2006): Facts and Analyses with Documents, (Salt Lake City: the University of Utah Press, 2006), 214.

${ }^{4}$ For more information on Greece's and Turkey's minority policies between 1923 and 1930 see D. Kamouzis, "Reciprocity or International Intervention? Greek and Turkish Minority Policy, 1923-1930”, in: Samim Akgönül ed. Reciprocity: Greek and Turkish Minorities, Law, Religion and Politics, (İstanbul: İstanbul Bilgi University Press, 2008), 49-67.

${ }^{5}$ For detailed information on the enactment and consequences of the Wealth Tax see. F. Ökte, Varlık Vergisi Faciası, (İstanbul: Nebioğlu Yayınevi, 1951); A. Aktar, Varlık Vergisi ve Türkleştirme Politikaları, 5. B., (İstanbul: İletişim Yayınları., 2001), 135-243; Apart from the
} 
actions damaged the trust between Greece and Turkey; this required time to vanquish

Nevertheless, during the 1950s, the top officials of Greece and Turkey continued to have reciprocal visits to improve their friendship. ${ }^{1}$ It is important to note that although people of both countries were displaying an interest in the Cyprus problem, their governments were avoiding the subject in order to secure the atmosphere of friendship and NATO interests. ${ }^{2}$ The first sign of the rapprochement between Ankara and Athens was in the election process of the new patriarch of Phanar (Fener) in which both parties agreed on Spiru Athenagoras, the Greek Orthodox Archbishop of North America. In the 1950s, minorities benefited from the relaxed atmosphere. Teachers taught in the minority schools in Western Thrace and in Greek minority schools in Turkey. In 1951, the Halki Theological Seminary began to accept students from Greece and other countries. Also, the use of Greek as the language of instruction in the schools of Gökçeada (Imbros) and Bozcaada (Tenedos) resumed. Students from Western Thrace obtained scholarships to attend teacher-training schools in Turkey. The minorities were granted permission to repair their schools in Western Thrace and the Celal Bayar High School; the first Muslim-minority high school in Western Thrace was opened by President Bayar during his visit to Greece. ${ }^{3}$

\section{Effects of the Cyprus Problem on the Minorities (1954-1990)}

The heyday of the minorities continued until the mid-1950s. Nevertheless, when the Cyprus problem emerged it had negative effects on the minorities and both Turkey and Greece used them as leverage to gain advantage in a situation of strained relations. Until the British asked Turkey to become a party in the Cyprus problem, she refrained from getting involved in the issue. When the Greek Cypriots aimed to unite with Greece (Enosis), and asked the British to leave the island, Turkey was also invited to the conference in London on 29 August 1955 to discuss the issues of the Eastern Mediterranean. Turkey was not satisfied in the conference and tried to push Greece to make more compromises regarding Cyprus. The events which took place in Turkey on 6-7 September 1955 caused the conference cease. Attacks were made on

Wealth Tax, some practices of the Turkish government in the interwar years violated the rights of the persons belonging to the non-Muslim minorities. For example, non-Muslim males from ages 18 to 45 were sent to the concentration camps under the name of "compulsory military service". For detailed information on this issue see R. N. Bali, Cumhuriyet Yillarında Türkiye Yahudileri: Bir Türkleştirme Serüveni 1923-1945, 6. B., (İstanbul: İletişi̇m Yayınlar, 2003), 408-423.

${ }^{1}$ H. T. Oğuzlu, "The Promise of NATO in the Constructing of Cooperative Turkish-Greek Relations", The Review of International Affairs 3, Spring: (2004), 462.

${ }^{2} \dot{I}$. Aslım, "American Foreign Policy on Cyprus (1960-1974)". (Ph.D. diss., Oulu University Press, 2010), 20.

${ }^{3}$ M. Firat, "Relations with Greece", in: B. Oran ed. Turkish Foreign Policy (1919-2006): Facts and Analyses with Documents, (Salt Lake City: the University of Utah Press, 2006), 348 and 353. 
properties, churches and schools belonging to the non-Muslims and also the Greek minority. During the events three Greeks were killed, thirty-five people were injured, and 5,652 buildings were destroyed. Greece protested the Turkish government while the Greek press claimed that the events were planned by the authorities of Turkey. ${ }^{1}$

The US intervened in the Greco-Turkish problems and the outcome was the establishment of the Republic of Cyprus (RoC). However, the nationalist powers of both parties in power destroyed the bi-communal structure of the Republic and the civil war started in Cyprus in $1964 .^{2}$ The 1964 Cyprus crisis had negative effects on the relevant minorities. During the crisis, the İnönü government adopted very tough policies towards the people of Greek origin in Turkey. Turkey decided to pressure Greek nationals in Turkey in order to get more concession from Greece. After the restrictive measures and anti-Greek atmosphere, 8,600 Greek citizens out of 12,724 were forced to leave Turkey. As a result, in 2000, only 1,500 to 2,000 members of the Greek minority still resided in Turkey. ${ }^{3}$ On 6 September 2014, the Human Rights Association of İstanbul announced the National Security Council of Turkey's decree no. 35, 27 May 1964, which aimed to carry out ethnic cleansing on Tenodos and Imbros. According to the decree, Turkey perceived Orthodox Greeks as an "enemy of Turks", "dangerous" and "Enosists". Also, the Greek minority schools were named as "the centers of sedition".

The principle of reciprocity was also implemented by Greece as retaliation. Turkish citizens residing in the Dodecanese Islands were deported. When the colonels took power in Greece in 1967, they continued the general policy of repression and expropriated the lands of the minority and minority villages came under military siege after each Cyprus crisis. ${ }^{5}$ Clearly, the minorities were the ones paying the price when the relations of Turkey and Greece were strained.

The confrontation of Turkey and Greece over the Aegean Sea and Cyprus in the 1970s continued the policy of reciprocity. However, as Greece turned to democracy, the Greek foreign policy was reoriented toward Europe and

\footnotetext{
${ }^{1}$ Ibid., 358-359; Alexandris, The Greek Minority of Istanbul and Greek-Turkish Relations (1918-1974), (Athens: Centre For Asia Minor Studies ,1992), 256-266. For more detailed information on the 6/7 September Events see D. Güven, Cumhuriyet Dönemi Azınlık Politikaları ve Stratejileri Bağlamında 6/7 Eylül Olayları, (İstanbul: İletişim Yayınları, 2006); S. Akgönül,. Türkiye Rumlarl: Ulus-Devlet Çağından Küreselleşme Çağına Bir Azınlığın Yok Oluş Süreci, (İstanbul: İletişim Yayınları, 2007), 177-224.

${ }^{2}$ The US mediation in Cyprus to solve Cyprus explains in Belcher, Airgram from Nicosia G-35, 12.12.58: doc. 747C.00/12-958, box 3285, NARA; Joseph, J. S. (1999), 38.

${ }^{3}$ M. Firat, "Relations with Greece", in: B. Oran ed. Turkish Foreign Policy (1919-2006): Facts and Analyses with Documents, (Salt Lake City: the University of Utah Press, 2006), 441-442. For detailed information on this issue see H. Demir and R. Akar, İstanbul'un Son Sürgünleri, (İstanbul: Belge Yayınları, 1999).

4“6-7 Eylül: MGK'nin 'etnik temizlik’ kararı”, Last Modified 9 September 2014, http:// www. birgun.net/news/view/6-7-eylul-mgknin-etnik-temizlik-karari/5050.

${ }^{5}$ M. Furat, Relations with Greece", in: B. Oran ed. Turkish Foreign Policy (1919-2006): Facts and Analyses with Documents, (Salt Lake City: the University of Utah Press, 2006), 442.
} 
membership in the European Economic Community (EEC). ${ }^{1}$ To decrease tension and improve the relations, on 17 April 1976 Karamanlis offered to settle all questions in a peaceful manner. However, Prime Minister Süleyman Demirel was unable to give a positive response because of national considerations. $^{2}$

In the 1983 elections, Turgut Özal, a neoliberal whose political vision was based on economic relations, came to power in Turkey. For Özal, the Cyprus problem and the dispute with Greece constrained Turkey's relations with the West and they had to be solved immediately. ${ }^{3}$ The prime ministers of Turkey and Greece, Özal and Andreas Papandreou, met on 30 and 31 January 1988 in Davos and decided to find a way for incessant solutions. ${ }^{4}$ However, it became clear that the goodwill of the leaders was not enough to achieve results unless there were adequate technical preparations.

\section{Changes in the Parameters of the Concept of Reciprocity (1990-2014)}

The collapse of the Soviet Union ended the Cold War and changed both international politics and the Greco-Turkish relations. Accordingly, the regional conflicts in the Balkans forced Turkey and Greece to improve their relations. ${ }^{5}$

However, the problems related with the rights of the Muslim-Turkish minority in Western Thrace began to receive international attention in 1980 before the collapse of the Soviet Union. With the 1975 Helsinki Final Act, human rights (and also minority rights) started to become significant. Greece's membership to the European Communities (EC) in 1981 bound it, by European standards. The Western Thracians' migration to the Federal Republic of Germany as workers ended the minority's isolation. Now they had closer contact with the world. Yet, the decision of the Greek High Court of Appeals, dated 4 November 1987 to cease the minority associations because the adjective "Turkish" was used in their titles resulted in the continuation of the tough policy toward the minority. The Muslim minority organized a demonstration on 29 January 1988; before the Davos talks, to attract the attention of the leaders of Turkey and Greece. However, the outcome was twenty injured demonstrators. Prime Minister Özal was very careful to avoid all controversial subjects with Greece. Minorities believed that they had been sacrificed for the success of the peace process. The minority continued to struggle for their rights and under the leadership of Sadik Ahmet, earned

\footnotetext{
${ }^{1}$ From Sisco to Secretary, Athens 4658, 19.7.1974: RG 59, Record of Joseph Sisco, 1951-1976, Cyprus Crisis, July 1974, Entry 5405, box 26, NARA, Doc. 99. [25 December 2007]

${ }^{2}$ R. Clogg, "Greek-Turkish Relations in the Post-1974 Period", in: D. Constas ed. The GreekTurkish Conflict in the 1990s, (Hampshire and London: Macmillan, 1991), 16.

${ }^{3}$ M. A. Birand, "Turkey and the 'Davos Process"”, in: D. Constas ed. The Greek-Turkish Conflict in the 1990s, (Hampshire and London: Macmillan, 1991), 28-33.

${ }^{4}$ Ibid., 33-34.

${ }^{5}$ T. Oğuzlu, "Soft Power in Turkish foreign policy", Australian Journal of International Affairs Affairs 61, no. 1, (March 2007): 85.
} 
widespread support of the public opinion. ${ }^{1}$ In the early 1990s the MuslimTurkish minority did not seek Turkey's support, but its voice was heard directly in Athens. Consequently, the minority in question of Western Thrace became a European issue and Athens began to be criticized at different international platforms; regarding her policies toward the minority in Western Thrace. $^{2}$

The first sign of a new friendship appeared in the meeting of TurkeyEuropean Union (EU) Association Council on 6 March 1995. There, the Custom Union was formally approved and Athens did not use her veto against Turkey. Clearly, Greece's attitude was very much related to the membership of RoC to the EU. As Greece refrained from vetoing against Turkey on the Custom Union, this prevented Turkey from opposing membership of the RoC to the EU. The following year Konstantinos Simitis and Foreign Minister George Papandreou realized the necessity of a new dialogue with Turkey. Papandreou met with İsmail Cem, the foreign minister of Turkey, and they decided to improve their relations in low politics and track-II diplomacy and to focus on high politics later. ${ }^{3}$ The earthquake diplomacy after August 1999 accelerated the process and citizens of Greece and Turkey provided aid for the victims. ${ }^{4}$ The earthquakes allowed the political elites in both countries to claim support for, and gain legitimacy in their policy transformation. The negative images began to change in both countries. ${ }^{5}$ Keridis is right when he points out that the citizens of Greece "are no longer hostages of the memories." 6 CyprusEU negotiations also normalized the relations between Greece and Turkey although the disputes in the Aegean and Cyprus were linked to Turkey's membership to the EU. ${ }^{7}$ On 28 May 2004, in a speech at Oxford University, Turkish Prime Minister, Recep Tayyip Erdoğan, declared with a great pleasure that; "if Turco-Greek rapprochement is possible today, it is because we have a

\footnotetext{
${ }^{1}$ B. Oran, Türk-Yunan İlişkilerinde Batı Trakya, 2. B., (Ankara: Bilgi Yayınevi, 1991), 188193.

${ }^{2}$ M. Firat, "Relations with Greece", in: B. Oran ed. Turkish Foreign Policy (1919-2006): Facts and Analyses with Documents, (Salt Lake City: the University of Utah Press, 2006), 791-792.

${ }^{3}$ İ. Cem, Türkiye, Avrupa, Avrasya, C. I, (İstanbul: İstanbul Bilgi Üniversitesi Yayınlar1 2004), 119-161; H. G Tzimitras, "Europeanization and Nationalism in the Turkish-Greek Rapprochement", Insight Turkey 10, no. 1 (2008): 111.

${ }^{4}$ M. Frrat, "Relations with Greece", in: B. Oran ed. Turkish Foreign Policy (1919-2006): Facts and Analyses with Documents, (Salt Lake City: the University of Utah Press, 2006), 814.

${ }^{5}$ H. G. Tzimitras, "Europeanization and Nationalism in the Turkish-Greek Rapprochement", Insight Turkey 10, no. 1 (2008): 112.

${ }^{6}$ D. Keridis, "Domestic Developments and Foreign Policy: Greek Policy Toward Turkey", in: D. Keridis and D. Triantaphyllon, eds. Greek Turkish Relations In The Era Of Globalization, (Massachusetts: Brassey's, 2001), 9.

${ }^{7}$ T. İlter, and D. Barlas, "Turkish-Greek Balance: A Key to Peace and Cooperation in the Balkans", East-European Quarterly 32, no. 4, (January 1994): 475-476; A. Kalaitzidis,. and D. Feslen, "Determinants to Greek Foreign Policy", Journal of Political and Military Sociology 35, no. 2, (Winter 2007): 230.
} 
common ground through which mutual perceptions are most accurate. That common ground is the EU." 1

Nevertheless, Europeanization of the relations between the parties could not resolve the problems of the minorities. For example, although contacts of the Patriarch with the world increased and he could conduct religious services at many places in Turkey, he was not very comfortable or happy. He even stressed his unhappiness during an interview with CBC. During the interview he said: "It is not a crime to live as a minority in Turkey. However, you feel that you are a second class citizen. The Patriarchate was founded almost 2,000 years ago but we are living under the control of a government which is expecting the dissolution of the patriarchate. This gives me a sense that I am waiting to be crucified". 2

Papandreou's letter to Erdoğan on 25 January 2010 gave the first sign that the government of Greece was aiming to change its mentality on the concept of reciprocity. Greece immediately announced some measures to ease the life of the Muslim-Turkish minority. Greece put the minority issues under the control of the Ministry of Interior to show that minorities would not be perceived as "foreigners" but as citizens. Without expecting any move from Turkey, Greece united some schools and published the Turkish books for the minorities. ${ }^{3}$ Although in Turkey there has been a trend to give more rights to the minorities, she has not made any attempts to do so regarding the Halki Seminary and the status of patriarch issues.

It is obvious that both Greece and Turkey are preparing themselves for new initiatives. For example, in 2011, the government of Greece prepared a proposal defining the process of election of the muftis by the Muslim-Turkish minority. ${ }^{4}$ However, it has been three years since it was first put forward but the proposal is still waiting to be implemented. On the other hand, on several occasions, some of the top officials of Turkey claimed that there was no legal obstacle in opening the Halki Seminary. For them the only missing thing was the political decision. ${ }^{5}$ It is interesting that during his visit to North Cyprus on September 1, 2014 President Erdoğan openly stated that the Government of Greece had promised him to construct two mosques in Athens but had not kept its promise. According to Erdoğan, "if the Government of Greece keeps its

\footnotetext{
${ }^{1}$ Speech by Prime Minister Recep Tayyip Erdoğan, "Why the EU Needs Turkey, Oxford, 28.5.2004. Available at http://www.sant.ox.ac.uk/esc/docs/Erdogan1.pdf, accessed 3 September 2013.

${ }^{2}$ Interview by Phanar Bartholomeos with CBC, "Kendimi Çarmıha Gerilmiş gibi Hissediyorum", 19.12.2009. Available at http://www.hurriyet.com.tr/dunya/13240618.asp. accessed 2 September 2014. For detailed information on the problems of Ecumenical Patriarchate see Dayığlu, A. (2013), 610-616.

${ }^{3}$ A. Dayığlu," Yunanistan'la İlişkiler", in: Baskın Oran ed. Türk Dış Politikası, Kurtuluş Savaşından Bugüne Olgular, Belgeler, Yorumlar, C. III, 2. B., (İstanbul, İletişim Yayınları, 2013), 593 and 596-597.

${ }^{4}$ Müftüler Fener Rum Patriği Gibi Seçilecek”, 28.6.2011,Available at 28.6.2011 http://www sabah.com.tr/Gundem/2011/06/28/muftuler-fener-rum-patrigi-gibi-secilecek, accesed 8 August 2014.

5“Hiç bir engel yok 24 saatte okul açılır", 5.7.2012, Available at : http://www.radikal.com.tr/ politika/hic engel_yok_24_saatte_okul_acilir-1093221, accesed: 11 September 2014.
} 
promise it is not very difficult to open the Halki Seminary". As can be seen, contrary to expectations, it seems that both Greece and Turkey are aiming to use reciprocity in the negative way.

\section{Conclusion}

As has been discussed above, even though Turkey-Greece relations have progressed in the post-1999 era and certain issues have been resolved thanks to the advances such as reciprocal visits of top officials of Turkey and Greece, activities of bilateral working groups and non-governmental organizations and joint projects, ${ }^{2}$ no progress has been made with regard to two important issues. Although Greece prepared a proposal to allow muftis to be elected to office, she could not continue to support her initiative due to their extensive secular authority. On the other hand, Turkey has stated re-opening of the Halki Seminary depends on positive action by Greece regarding Turkish schools, muftis, and the mosque in Athens ${ }^{3}$ The main reason of this situation was that both Turkey and Greece, as mentioned above, have not taken their minority issues within humanitarian and lawful context. The parties have acted within the context of principle of reciprocity, the principle that cannot exercised on

\footnotetext{
${ }^{1}$ Speech by President Recep Tayyip Erdoğan, "Cumhurbaşkanı Erdoğan: Tribünde Seyirci Değiliz". Available at http://www.hurriyet.com.tr/gundem/27122551.asp. accesed: 1 September 2014.

${ }^{2}$ For these advances see L. Karakatsanis, Turkish-Greek Relations: Rapprochement, Civil Society and the Politics of Friendship, (London and New York: Routledge, 2014).

${ }^{3}$ Although some problems continued to exist after 1999, the EU connection and rapprochement between the two countries made positive impact on the issues of Muslim-Turkish and Greek minorities. For example, an extension building has been added to one of the two minority secondary schools, the Celal Bayar Secondary School in 2004-2005. Between 1997 and 2007 three-stage "Program for the Education of Moslem Children" sponsored by the EU has been implemented. Moreover in 2007, a Turkish lecture book has been prepared for the state schools of Western Thrace. There were some positive developments in other fields as well. For example, in the 2000s the Greek administration has begun to restore the mosques in Rhodes and Kos using the financial support of the EU. Also, in 2006 the Greek Parliament accepted a law easing the procedure to get a license for building a new mosque. Moreover, with the new Foundation Act dated 2008, the members of Muslim-Turkish minority has been given 5 per thousand quota in the entrance examinations of the state departments and positive arrangements has been done regarding their foundation assets in Greece.

In the post-1999 era, Turkey, like Greece, had some positive steps. For example, on 13 May 2010, the Prime Ministerial Circular no 27580 has aimed to solve the problems of nonMuslims -Greek minorities included- faced in different areas. On 15 August 2010, a religious service has been run by Patriarchate Bartholomeos at Sümela Monastry (Moní Panagías Soumelá) for the first time in 88 years. At the same year, the Turkish government gave citizenship to 17 metropolitan bishops to ensure the continuance of the activities of Patriarchate. Furthermore, many churches in Turkey have been restored and in 2013 the Greek minority school in Gökçeada has become functional which was closed in 1964. For detailed information on these developments see A. Dayığlu, Yunanistan'la İlişkiler”, in: Baskın Oran ed. Türk Dış Politikası, Kurtuluş Savaşından Bugüne Olgular, Belgeler, Yorumlar, C. III, 2. B., (İstanbul, İletişim Yayınları, 2013), 593-621.
} 
humanitarian issues and on their own citizens. What is essential is taking the necessary steps to resolve the problems of their own citizens. It appears that the most reasonable solution would be to strip the muftis of their authority regarding jurisdiction and permit their election to office. In this way, Greece's fears will be allayed and the issue of the election of muftis to office will be resolved and Greece will earn the trust of her Muslim-Turkish citizens. Surely, nothing could be more important for a state to have "voluntary" citizens rather than "compulsory" citizens.

On the other hand, Turkey has to stop binding the opening of the Halki Seminary to the condition of reciprocity; make the necessary changes in statute laws (if such a need) and open the Seminary. In turn, the Ecumenical Patriarchate of Istanbul, which is deemed to be primus inter pares within the Orthodox world, will have its need for clergymen met, and Turkey's full membership process to the EU will gain momentum. More importantly, the Greek Orthodox population which is on the verge of extinction in Istanbul will increase with the opening of the Seminary, and thus, İstanbul will regain its old cosmopolitan structure and cultural richness.

Finally, Turkey and Greece have to change their mentality of using their own citizens for national interests and power politics. The only way is to follow George Papandreou's line as mentioned above: 'To see the minorities as citizens not foreigners.'

\section{References}

Documents of US National Archives and Record Administration.

“6-7 Eylül: MGK'nın 'Etnik Temizlik' Kararı” (6-7 September: Ethnic Cleansing Decision of the National Security Council), 06.09.2014, Available at http://www. birgun.net/news/view/6-7-eylul-mgknin-etnik-temizlik-karari/5050. Accesed: 9 September 2014.

Speech by President Recep Tayyip Erdoğan, "Cumhurbaşkanı Erdoğan: Tribünde Seyirci Değiliz" (President Erdoğan: We Are Not Spectators in the Tribune), Available at http://www.hurriyet.com.tr/gundem/27122551.asp. Accessed: 1 September 2014.

Speech by Prime Minister Recep Tayyip Erdoğan, "Why the EU Needs Turkey, Oxford, 28.5.2004. Available at http://www.sant.ox.ac.uk/esc/docs/Erdogan1.pdf. accessed: 3 September 2013.

Interview by Phanar Bartholomeos with CBC, "Kendimi Çarmıha Gerilmiş gibi Hissediyorum" (I Am Feeling Myself as Waiting to be Crucified), 19.12.2009, Available at http://www.hurriyet.com.tr/dunya/13240618.asp, accesed: 2 September 2014.

"Müftüler Fener Rum Patriği Gibi Seçilecek" (Muftis will be Elected like the Patricate of Phanar), 28.6.2011, Available at http://www.sabah.com.tr/Gundem/2011/06/ 28/muftuler-fener-rum-patrigi-gibi-secilecek, accesed: 8 August 2014.

"Hiç bir engel yok 24 saatte okul açılır" (There is no obstacle school can open within 24 hours), 5.7.2012, http://www.radikal.com.tr/politika/hic_engel_yok_24_saatte _okul_acilir-1093221. accesed: 11 September 2014. 
Books and Books Chapters

Akgönül, S. Türkiye Rumları: Ulus-Devlet Çă̆ından Küreselleşme Çağına Bir Azınlığın Yok Oluş Süreci (The Greeks-Rums of Turkey: The Destruction Process of a Minoryty from the Nation State to Globalization Era), İstanbul: İletişim Yayınları, 2007.

Akgönül, S. "Reciprocity and its Application in International Law", in: Samim Akgönül (ed.), Reciprocity: Greek and Turkish Minorities, Law, Religion and Politics, İstanbul, İstanbul Bilgi University Press, 2008, 1-14.

Aktar, A. Varlık Vergisi ve Türkleştirme Politikaları (Wealth Tax and Policy of Turkification), 5. B., İstanbul: İletişim Yayınları, 2001.

Alexandris, A. The Greek Minority of İstanbul and Greek-Turkish Relations (19181974), Athens: Centre for Asia Minor Studies, 1992.

Bali, R. N. Cumhuriyet Yıllarında Türkiye Yahudileri: Bir Türkleştirme Serüveni 1923-1945 (The Jews of Turkey during the Period of the Republic: An Adventure of Turkification 1923-1945), 6. B., İstanbul: İletişim Yayınları, 2003.

Birand, M. A. "Turkey and the 'Davos Process"”, in: D. Constas ed. The GreekTurkish Conflict in the 1990s, Hampshire and London: Macmillan, 1991, 27-39.

Cem, İ. Türkiye, Avrupa, Avrasya (Turkey, Europe, Eurasia), C. I, İstanbul, İstanbul Bilgi Üniversitesi Yayınları, 2004.

Cin, T. Yunanistan'daki Müslüman Türk Azınlı̆̆ın Din ve Vicdan Özgürlüğü: Başmüftülük ve Müftülükler Sorunu (Freedom of Religion and Conscience of Muslim-Turkish in Greece: The Problem of Head Muftiate and Muftis), Ankara: Seçkin Yayıncılık, 2003.

Clogg, R. "Greek-Turkish Relations in the Post-1974 Period", in: D. Constas ed. The Greek-Turkish Conflict in the 1990s, Hampshire and London: Macmillan, 1991, 12-23.

Dayığlu, A. "Yunanistan'la İlişkiler" (Relations with Greece), in: Baskın Oran ed. Türk Dış Politikası, Kurtuluş Savaşından Bugüne Olgular, Belgeler, Yorumlar (Turkish Foreign Policy, From the War of Independence to the Present, Facts, Documents, Comments), C. III, 2. B., İstanbul, İletişim Yayınları, 2013, 560-631.

Demir, H. and R. Akar. Ístanbul'un Son Sürgünleri (The Last Exiled of İstanbul), İstanbul: Belge Yayınları, 1999.

Demirözü, D. Atatürk-Venizelos Dönemi Türkiye Yunanistan İlişkileri (Turkey-Greece Relations in the Period of Atatürk and Venizelos), İstanbul: İletişim, 2007.

Firat, M. "Relations with Greece", in: B. Oran (ed.), Turkish Foreign Policy (19192006): Facts and Analyses with Documents, Salt Lake City: the University of Utah Press, 2006. 195-215, 344-367, 432-463, 790-816.

Güven, D. Cumhuriyet Dönemi Azınlı Politikaları ve Stratejileri Bağlamında 6/7 Eylül Olaylart (The 6-7 Events within the Context of Minority Policies and Strategies of Republic Period), İstanbul: İletişim Yayınları, 2006.

Hirschon, R. ed., Ege'yi Geçerken: 1923 Türk-Yunan Zorunlu Nüfus Mübadelesi (Crossing the Aegean: An Appraisal of the 1923 Compulsory Population Exchange Between Greece and Turkey), İstanbul: İstanbul Bilgi Üniversitesi Yayınlar1, 2005.

Karakatsanis, L. Turkish-Greek Relations: Rapprochement, Civil Society and the Politics of Friendship, London and New York: Routledge, 2014.

Joseph, J. S. Cyprus: Ethnic Conflict and International Politics: From Independence to Threshold of the European Union, London: Macmillan Press Ltd, 1999. 
Keridis, D. "Domestic Developments and Foreign Policy: Greek Policy toward Turkey", in: D. Keridis and D. Triantaphyllon, ed. Greek Turkish Relations In The Era Of Globalization, Massachusetts: Brassey's, 2001, 2-18.

Kamouzis, D. "Reciprocity or International Intervention? Greek and Turkish Minority Policy, 1923-1930", in: Samim Akgönül (ed.), Reciprocity: Greek and Turkish Minorities, Law, Religion and Politics, İstanbul, İstanbul Bilgi University Press, 2008, 49-67.

Pekin M. ed., Yeniden Kurulan Yaşamlar: 1923 Türk-Yunan Zorunlu Nüfus Mübadelesi (The Re-constucting Lifes: Turk-Greek Compulsory Population Exchange), İstanbul: İstanbul Bilgi Üniversitesi Yayınları, 2005.

Poulton, H. Top Hat Grey Wolf and Crescent: Turkish Nationalism and the Turkish Republic. London: Hurst \& Company, 1997.

Oran, B. Türk-Yunan Iliş̧kilerinde Batı Trakya Sorunu (The Western Thrace Minority Question in Turco-Greek Relations) 2. B., Ankara, Bilgi Yayınevi, 1991.

Oran, B. "Reciprocity in Turco-Greek relations: The Case of Minorities", in: Samim Akgönül ed., Reciprocity: Greek and Turkish Minorities, Law, Religion and Politics, İstanbul, İstanbul Bilgi University Press, 2008, 35-38.

Ökte, F. Varlık Vergisi Faciası (The Tragedy of the Wealth Tax), İstanbul: Nebioğlu Yayınevi, 1951.

Tarhanlı, T. "Turgut Tarhanlı'nın Bildirisi (Presentation of Turgut Tarhanlı)", in: Cemaat Vakıfları, Bugünkü Sorunları ve Çözüm Önerileri (Community Foundations, Their Current Problems and Solution Suggestions), İstanbul, İstanbul Barosu Yayın1, 2002, 34-45.

Yıldırım, O. Diplomasi ve Göç: Türk-Yunan Diplomasisinin Öteki Yüzü,(Diplomacy and Migration: The Other Face of Turk-Greek Diplomacy), İstanbul: İstanbul Bilgi Üniversitesi Yayınları, 2006.

Zürcher, E. J. Modernleşen Türkiye'nin Tarihi (Turkey, A Modern History), İstanbul: İletişim Yayıncılık A.Ş, 1995.

Journal Articles

İlter, T. and Barlas, D. "Turkish-Greek Balance: A Key to Peace and Cooperation in the Balkans", East-European Quarterly 32, no. 4, (January 1994): 469-488.

Kalaitzidis, A. and Feslen D. "Adding the Domestic Determinants to Greek Foreign Policy", Journal of Political and Military Sociology 35, no. 2, (Winter 2007): 219-235.

Oğuzlu, H. T. "The Promise of NATO in the Constructing of Cooperative TurkishGreek Relations", The Review of International Affairs 3, (Spring 2004): 458-478.

Oğuzlu, H. T. "Soft Power in Turkish foreign policy", Australian Journal of International Affairs 61, no. 1, (March 2007): 81-97.

Tzimitras, H. G. "Europeanization and Nationalism in the Turkish-Greek Rapprochement", Insight Turkey 10, no. 1 (2008): 111-128.

Thesis and Dissertations

Aslım, İ. American Foreign Policy on Cyprus (1960-1974). Ph.D. diss., Oulu University Press, 2010. 
